\title{
PENGOLAHAN GULA SEMUT DI DESA MABAR KECAMATAN BANGUN PURBA KABUPATEN SERDANG BEDAGAI
}

\author{
Sri Wahyuni ${ }^{1}$, Bambang Hermanto ${ }^{2)}$, Munawaroh ${ }^{3)}$, Farida Yani ${ }^{4)}$ \\ Universitas Muslim Nusantara (UMN) Al Washliyah ${ }^{1)}$ \\ Universitas Muslim Nusantara (UMN) Al Washliyah ${ }^{2)}$ \\ Universitas Muslim Nusantara (UMN) Al Washliyah ${ }^{3)}$ \\ Universitas Muslim Nusantara (UMN) Al Washliyah ${ }^{4)}$ \\ sriwahyuni@umnaw.ac.id
}

\begin{abstract}
ABSTRAK
Konsumsi gula di Indonesia yang tidak diimbangi dengan meningkatnya produksi gula di dalam negeri menyebabkan impor gula semakin meningkat. Nira aren umumnya diolah menjadi gula merah yang mana pembuatan dari gula merah tersebut memerlukan waktu relatif lama, kurang praktis oleh sebab itu, Gula semut merupakan salah satu alternatif yang dapat dilakukan untuk mengatasi beberapa kelemahan gula merah aren.Tujuan dari program pengabdian masyarakat ini adalah membina dan meningkatkan pendapatan petani nira aren melalui produk diversifikasi dari nira aren, mensosialisasikan kepada warga di desa tersebut.Metode pendekatan yang digunakan dalam pelaksanaan Pengabdian Masyarakat ini adalah dengan cara memperkenalkan produk diversifikasi gula semut, serta manfaat yang dapat diperoleh, memberikan pelatihan pembuatan gula semut.Hasil pelaksanaan kegiatan pengabdian ini setelah dilakukan pelatihan menunjukkan bahwa $74 \%$ peserta menyatakan materi yang disampaikan menarik, $55 \%$ menyatakan paham terhadap penjelasan materi, $78 \%$ menyatakan paham mengenai cara pembuatan produk diversifikasi ini, $56 \%$ menyatakan berminat terhadap pengembangan usaha gula semut.
\end{abstract}

Kata Kunci : Gula semut,Diversifikasi,Nira

\begin{abstract}
Sugar consumption in Indonesia which is not balanced with an increase in domestic sugar production causes sugar imports to increase. Palm sap is generally processed into brown sugar which making from the brown sugar requires a relatively long time, less practical therefore, Brown sugar is one alternative that can be done to overcome some weaknesses of palm sugar. The aim of this community service program is to foster and increasing the income of palm sugar farmers through diversification products from palm sugar, socializing to residents in the village. The method of approach used in the implementation of Community Service is by introducing an ant sugar diversification product, as well as the benefits that can be obtained, providing training in the production of Palm sugar. The results of the implementation of this community service activity after the training showed that $74 \%$ of participants stated that the material presented was interesting, $55 \%$ expressed understanding of the material explanation, $78 \%$ expressed understanding of how to manufacture this diversified product, $56 \%$ expressed interest in developing the ant sugar saha.
\end{abstract}

Keywords: Brown sugar, Diversification, roomie.

\section{PENDAHULUAN}

Masyarakat Republik Indonesia sebagian besar bergerak dibidang pertanian dan perkebunan oleh karena itu Pembangunan disektor pertanian dan perkebunan memiliki peranan yang sangat penting dalam meningkatkan Pendapatan Nasional. Salah satu komoditas perkebunan yang memiliki nilai ekonomis adalah Gula
Aren (Arrenga pinnata Merr), terutama nira yang diambil dari hasil penyadapan bunganya. Gula aren merupakan salah satu bahan pemanis yang banyak digunakan dalam pengolahan makanan di tingkat rumah tangga maupun di berbagai industri makanan olahan tradisional. Di Indonesia banyak makanan ataupun minuman yang 
menggunakan gula merah untuk olahan. Pada umumnya, gula merah berupa gula batok (gula merah padat).

Proses pembuatan gula batok masih dilakukan secara tradisional di beberapa daerah di Indonesia dan bentuknya tidak bervariasi selanjutnya Pembuatan gula merah padat ini membutuhkan energi untuk membentuk nira menjadi gula batok, ketika gula batok tersebut akan diolah menjadi panganan maka gula tersebut harus diencerkan kembali. Hal ini dinilai kurang efisien dalam penggunaan energi dan tidak efektif dari segi waktu. Sedangkan proses pengolahan dalam bentuk gula semut dapat digunakan langsung. Desa Mabar Kecamatan Bangun Purba merupakan daerah yang memiliki lahan perkebunan aren yang cukup luas Sehingga daerah ini mempunyai peluang investasi yang besar dalam lingkup penghasil nira aren.

Alternatif diversifikasi gula aren akan mampu membantu petani aren dan Usaha Kecil Menengah (UKM) penghasil gula merah dalam upaya diversifikasi produk gula aren cetak (gula merah). Program diversifikasi gula semut mampu membantu pemerintah dalam upaya pembuatan diversifikasi olahan nira aren berbahan baku non-tebu. Keunggulan gula semut yaitu memiliki daya simpan dalam waktu yang relatif lama. Selain itu, gula semut mempunyai kelebihan dalam pemakaiannya, yaitu lebih mudah larut dalam air sehingga praktis untuk dikonsumsi. Proses gula semut pun lebih efisien dan tidak menghabiskan energy dan waktu yang terlalu banyak. Sehingga pembuatan gula akan menjadi peluang usaha yang prospektif bagi masyarakat Desa Mabar Kecamatan Bangun Purba.

\section{Permasalahan Mitra}

Berdasarkan data observasi dan wawancara langsung dengan mitra. Adapun permasalahan yang dihadapi mitra adalah sebagai berikut:

1. Kendala biaya yang dibutuhkan untuk membuat usaha diversifikasi dari nira aren menjadi gula semut.

2. Minimnya sarana dan prasarana produksi berupa alat-alat produksi untuk kelancaran proses produksi gula semut.

3. Kurangnya pengetahuan tentang pemanfaatan tanaman aren menjadi olahan produk gula semut di Desa Mabar Kecamatan Bangun Purba.

4. Belum memiliki pengetahuan tentang membuat sediaan diversivikasi olahan produk nira.

5. Kurangnya pengetahuan sistem manajemen usaha sehingga diperlukan pelatihan dan ketrampilan agar dapat professional dalam menata manajemen usaha berupa pembukuan, keuangan, laporan pemasukan dan pengeluaran serta pemasaran produk secara langsung maupun secara online melalui internet.

6. Kurangnya motivasi dalam melakukan kegiatan usaha diversifikasi produk nira aren, dengan memberikan motivasi dan dorongan agar masing-masing mitra dapat menjadi pengusaha yang sukses dan menjadi salah satu sumber lapangan kerja di Desa Mabar Kecamatan Bangun Purba. 


\section{METODE PELAKSANAAN}

Metode kegiatan Program Pengabdian Kepada Masyarakat ini terdiri dari tahapan:

Berdasarkan permasalahan mitra, adapun untuk mencapai tujuan yang akan dicapai maka:

I. Tahap persiapan yang dilakukan adalah melakukan sosialisasi dan penyuluhan :

\section{a. Sosialisasi}

Metode ini digunakan untuk memberikan wawasan tentang kewirausahaan dan meningkatkan pemahaman pengetahuan dan ketrampilan dalam hal diversifikasi produk, sehingga dapat meningkatkan nilai tambah. Metode ini digunakan untuk meningkatkan pengetahuan mitra tentang manajemen usaha.

\section{b. Penyuluhan/Edukasi}

Metode ini digunakan untuk melihat pemahaman dan ketrampilan tentang upaya meningkatkan nilai tambah air nira menjadi gula semut.

\section{Tahap Pendampingan}

Metode pendampingan meliputi pengolahan dan pengawasan yang digunakan untuk melihat peserta sejauh mana memahami penjelasan dari materi yang di uraikan untuk pembuatan gula semut.

\section{HASIL}

Dari hasil pengabdian masyarakat yang dilaksanakan di Desa Mabar Kecamatan Bangun Purba Kabupaten Deli Serdang terdapat perbedaan yang signifikant terhadap kegiatan yang telah dilaksanakan di desa tersebut, kegiatan tersebut dapat terlihat dari :

\section{Kegiatan Sosialisasi}

Peserta Kegiatan sosialisasi ini adalah pengrajin gula aren yang memiliki karyawan 4-5 orang. Respon dan tingkat partisipasi yang diberikan pada saat sosialisasi ini terlihat dari reaksi peserta yang dapat memahami materi yang disampaikan oleh pemateri sehingga diskusi berjalan lancar. Kegiatan sosialisasi pengabdian ini dapat terukur dengan membagikan kuesioner sebelum dan sesudah kegiatan. Dari hasil sosialisasi tersebut terlihat bahwa: Peningkatan Pengetahuan Tentang Pengolahan Produk Diversivikasi aren di Desa Mabar Kecamatan Bangun Purba Kabupaten Deli Serdang. Hasil yang telah dicapai dalam kegiatan Pengabdian kepada Masyarakat ini berupa peningkatan pengetahuan tentang nilai tambah suatu produk. Hal ini dapat terlihat dari hasil kuisioner yang diambil dari peserta yaitu :

\begin{tabular}{|l|l|c|c|}
\hline \multicolumn{1}{|c|}{ Variabel } & \multicolumn{1}{|c|}{ Indikator } & Jumlah & Persentase \\
\hline $\begin{array}{l}\text { Penyampaian } \\
\text { Materi }\end{array}$ & $\begin{array}{l}\text { 1. Rasa tertarik terhadap } \\
\text { materi }\end{array}$ & 37 & $74 \%$ \\
\cline { 2 - 4 } & $\begin{array}{l}\text { 2. Pemahaman terhadap } \\
\text { Materi }\end{array}$ & 27 & $55 \%$ \\
\hline $\begin{array}{l}\text { Pengolahan } \\
\text { Produk }\end{array}$ & $\begin{array}{l}\text { Pemahaman cara proses } \\
\text { pembuatan pengolahan } \\
\text { produk diversifikasi }\end{array}$ & 39 & $78 \%$ \\
\hline $\begin{array}{l}\text { Pengembangan } \\
\begin{array}{l}\text { Usaha Produk } \\
\text { Diversifikasi } \\
\text { Aren }\end{array}\end{array}$ & $\begin{array}{l}\text { Pemahaman dan minat } \\
\text { pengembagan usaha } \\
\text { produk diversifikasi gula } \\
\text { aren }\end{array}$ & 28 & $56 \%$ \\
\hline
\end{tabular}

Tabel 1. Persentase kuisioner tentang pemahaman produk diversifikasi 
Dari tabel 1. diatas terlihat bahwa kelompok tani di desa mabar kecamatan bangun purba kabupaten deli serdang sangat tertarik dengan persentase $74 \%$ dan paham dengan persentase $55 \%$ terhadap materi yang disampaikan. Dari persentase tersebut menunjukkan bahwa petani aren di desa mabar sangat antusias untuk mengikuti kegiatan pengabdian masyarakat karena meningkatkan pengetahuan tentang diversifikasi produk dari nira aren menjadi gula cair dan gula semut. Selain itu, masalah yang lain kegiatan ini menguntungkan masyarakat karena dapat mengembangkan jiwa wirausaha.

\section{Sarana Prasarana dan} Pendapatan

Sarana Prasarana merupakan alat yang digunakan untuk memudahkan pekerjaan seseorang. Berdasarkan informasi yang diperoleh dari wawancara dan pengamatan langsung di Desa Mabar Kecamatan Bangun Purba, bahwa ada beberapa hal yang dibutuhkan mereka untuk membuat produk diversifikasi dari aren ini, karena biasanya produk aren hanya sebatas gula cetak, oleh sebab itu mereka sangat membutuhkan sarana dan prasarana untuk membuat produk diversifikasi dari aren ini, antara lain:

a. Pelatihan pembuatan gula semut karena sebahagian besar mereka tidak mengetahui pembuatan gula semut.

b. Pengrajin aren membutuhkan peralatan yang berbasis teknologi seperti mesin pembuat gula semut hal tersebut karena selama proses produksi para pengrajin masih menggunakan peralatan tradisional yang menyebabkan terhambatnya proses produksi.

c. Pelatihan terkait manajemen keuangan dan manajemen pasar karena selama ini pengelolaan keuangan serta pasar untuk mendistribusikan produk ini masih belum banyak.

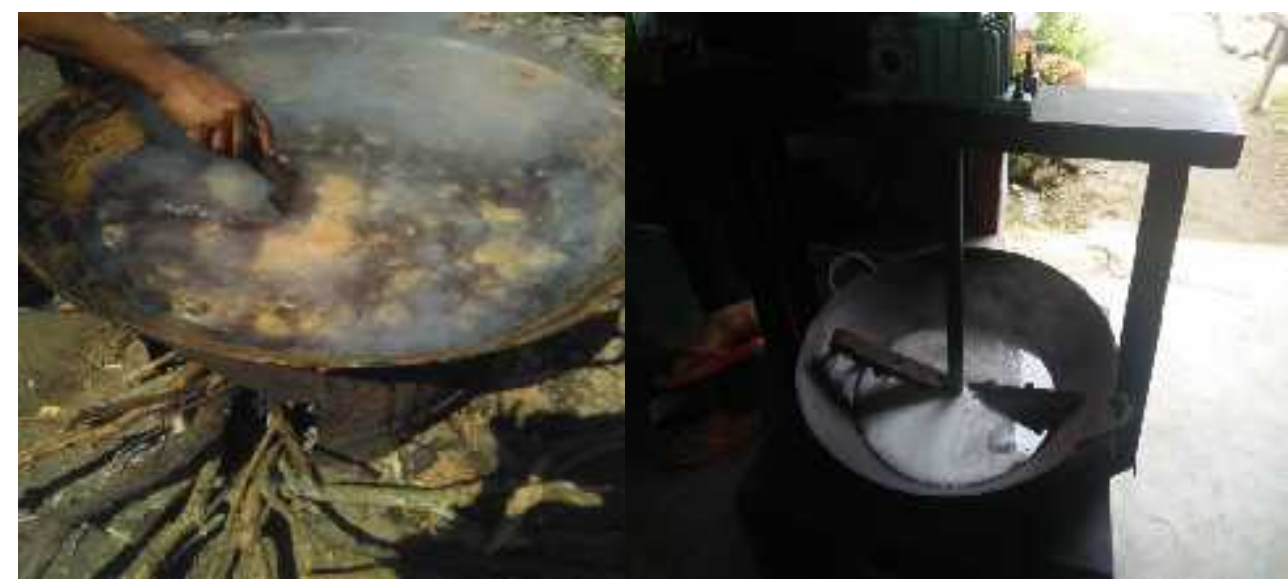

(A)
(B)

Gambar 1. Peralatan Pembuatan Gula Aren Tradisional (A), Peralatan Gula Semut (B)

Dari kebutuhan yang diperlukan oleh para pengrajin, maka setelah kegiatan Pengabdian Kepada
Masyarakat ini banyak perubahan yang terlihat mulai dari pendapatan mereka yang bertambah. 
d. Tingkat Pendapatan Sebelum dilaksanakan kegiatan Pengabdian Kepada Masyarakat, para petani/pengrajin gula aren hanya menjual sebatas gula cetak dengan harga per kg nya yaitu Rp.20.000, sedangkan di pasar harganya sekitar Rp.13.000/kg jauh lebih murah, padahal mutu dari aren yang dipasar kebanyakan gulanya dioplos yaitu bukan gula aren murni akan tetapi dicampur dengan bahan yang lain untuk di pasarkan ke konsumen. Untuk nira aren mentah terkadang masih dijual mereka pada pengusaha kue dan pengusaha tuak dengan harga jauh lebih rendah yaitu Rp.3000/liter nya. Oleh sebab itu kegiatan ini tidak dapat diandalkan untuk perekonomian keluarga. Dalam pelaksanaan kegiatan ini, masalah yang dihadapi petani aren tersebut dapat diatasi dengan cara membuat produk lain melalui program diversifikasi membuat gula semut, selain itu Solusi dari kendala yang dihadapi yaitu mencari pemasaran yang tepat dan alternatif untuk memasarkan produk ini langsung ke konsumen untuk mencegah terjadinya produk tiruan sehingga dapat layak dikonsumsi oleh masyarakat secara aman. Selain itu, kegiatan pengolahan produk diversifikasi menjadi gula semut yang harganya jauh lebih tinggi yaitu Rp. 50.000- 60.000 per kg dari pengolahan diversifikasi ini cukup significant dapat menambah pendapatan petani aren dan layak untuk dikonsumsi oleh konsumen.

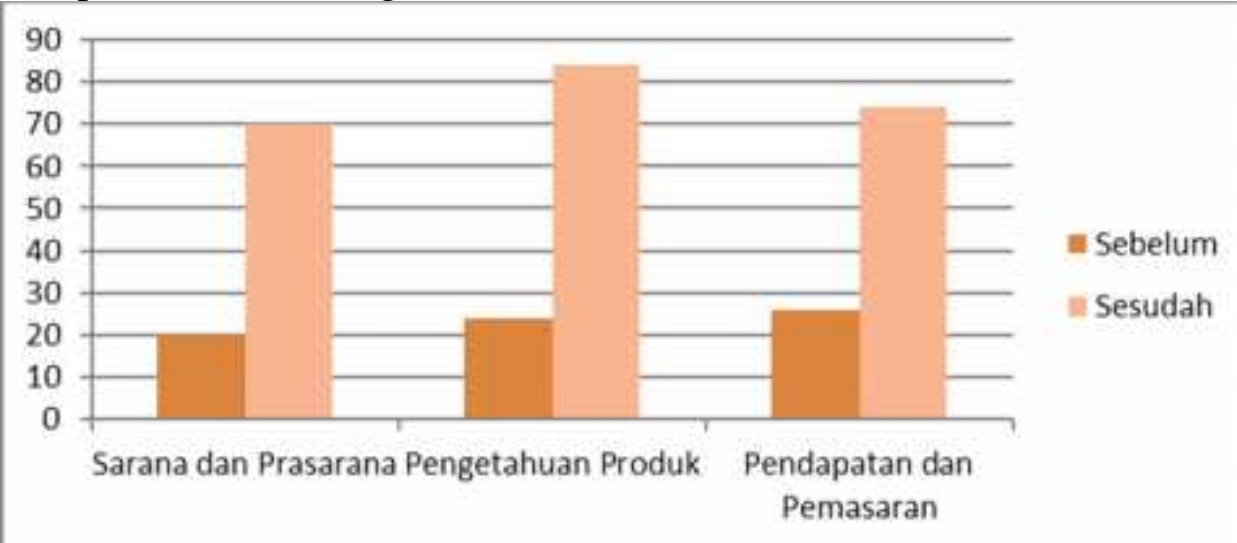

Gambar 2. Grafik Persentase sebelum dan sedah Kegiatan Pengabdian Masyarakat

Berdasarkan kegiatan diatas dapat digambarkan dalam gambar grafik sebelum dan sesudah kegiatan mulai dari sarana prasarana, pengetahuan produk dan manajemen pemasaran mengalami peningkatan yang significant dari sebelum dan sesudah kegiatan pengabdian masyarakat. 


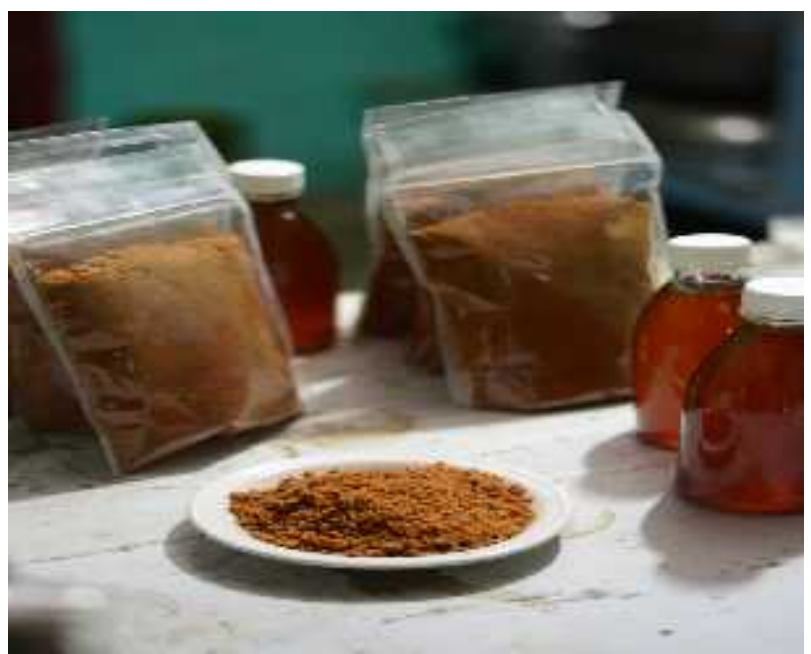

Gambar 3. (a) Produk Gula semut

\section{Kesimpulan}

Hasil kegiatan Pengabdian masyarakat ini dapat disimpulkan sebagai berikut :

1. Terdapat perubahan pola pikir petani kearah pengembangan usaha diversifikasi olahan tanaman aren menjadi gula semut.

2. Peningkatan pemahaman tentang produk olahan dari gula tradisional menjadi olahan produk diversifikasi sehingga akan menambah nilai suatu produk

3. Meningkatkan Pendapatan petani aren, selain dari gula cetak melalui kegiatan diversifikasi ini.

\section{REFERENSI}

Dinas Kehutanan Provinsi Jawa Tengah.

http://lumbungmedia.com/.

Budidaya dan Potensi Tanaman Aren. Diakses Tanggal 2 November 2013

Fajariyah, Maya. 2010. Produktivitas Pembuatan Gula Aren (Arenga Pinnata Merr) dan Kontribusinya Terhadap Pendapatan Masyarakat di Desa Guntung Kecamatan Haruyan Kabupaten Hulu Sungai Tengah. Skripsi.
Fakultas

Kehutanan Universitas Mangkurat, Banjarbaru.

Lambung

$$
\text { . J. 2002 Bisnis }
$$

Hafsah, M. J. 2002. Bisnis Gula di Indonesia. Pustaka Sinar Harapan. Jakarta.

Hopkins, D. 1993. A Techer's Guide to Classroom Research. Buckingham : Open University Press.

Mujayyin Kholik Heri, Mohammad Lukman, 2005, Laporan akhir pengabdian pada Masyarakat Pendampingan Penerapan Metoda Pengendalian Kualitas Statistik untuk Peningkatan Kualitas Proses Produksi gula Kelapa/ Merah (Studi Kasus di Sentra Industri Gula Merah Desa "Candi' Kec. Ponggok Blitar). 